\title{
Lipidized Fibrous Histiocytoma: Differential Diagnosis from Juvenile Xanthogranuloma
}

\author{
Jong-Kil Seo, Eun-Jae Shin, Ki-Heon Jeong, Min Kyung Shin \\ Department of Dermatology, School of Medicine, Kyung Hee University, Seoul, Korea
}

Dear Editor:

Fibrous histiocytoma $(\mathrm{FH})$ is one of the most common benign tumors of the skin and represents a group of mesenchymal lesions with histiocytic, fibroblastic, and myofibroblastic differentiation ${ }^{1}$. Cutaneous $\mathrm{FH}$ has been clinically characterized as a solitary, raised, round, red-brown, and firm nodule measuring about $1 \mathrm{~cm}$ in diameter ${ }^{1}$. It most often occurs on the extremities of young or middle-aged adults and shows a slight female predominance ${ }^{2}$. Several clinicopathologic variants of $\mathrm{FH}$ have been described and include cellular benign $\mathrm{FH}$, aneurysmal $\mathrm{FH}$, epithelioid cell $\mathrm{FH}$, atypical $\mathrm{FH}$, deep penetrating $\mathrm{FH}$, and lipidized $\mathrm{FH}^{1,2}$.

Lipidized $\mathrm{FH}$ is a subtype of $\mathrm{FH}$ that is relatively rarely observed, accounting for $2.1 \%$ of the variants of $\mathrm{FH}^{3}$. It most commonly develops in the lower limbs, so it has been previously called "ankle-type" FH. In comparison to other variants, it appears clinically as a large exophytic yellow nodule around the ankle $\mathrm{e}^{3}$. We herein report a case of an unusual histological variant of $\mathrm{FH}$ presenting clinically as a juvenile xanthogranuloma (XG)-like lesion and describe the tumor using histological and immunohistological techniques.

In the current case, a 33-year-old male presented to our hospital with an asymptomatic papule on the left forearm area that had been present for 6 months. Physical examination revealed a single non-tender, erythematous to yellowish-colored, firm, hairless papule that was $5 \times 6 \mathrm{~mm}$ in diameter (Fig. 1A). The tumor was completely removed by punch excision. Histopathological examination revealed a dermal tumor that abutted the epidermis and extended into the subcutis (Fig. 1B). Epidermal hyperplasia with hyperkeratosis was present. The tumor was comprised of proliferating histiocytoid cells and fibroblast-like spindle cells in a storiform pattern. Vascular proliferation and sclerotic collagen bundles were noted. High magnification imaging revealed a dense infiltration of numerous foam cells that were oval to polygonal in shape with large hypochromatic nuclei, prominent nucleoli, and abundant vacuolated cytoplasm (Fig. 1C). Binucleated or multinucleated Touton-type giant cells were also present. Immunohistochemical staining was positive for CD68, focally positive for CD34, especially in the peripheral region of the lesion, and negative for S-100 and leukocyte common antigen (Fig. 1D). The foam cells showed diffuse cytoplasmic staining for CD68. Finally, the patient was diagnosed with lipidized $\mathrm{FH}$ based on the pattern of histology and immunohistochemistry.

Lipidized FH was identified in 1994 as a single exophytic yellowish nodule composed of foamy macrophage that had a predilection for the ankle ${ }^{1}$. It is a rare and underrecognized variant of $\mathrm{FH}$ that needs to be distinguished from juvenile $X G^{1}$. Juvenile $X G$ is a common benign histiocytic skin tumor that affects preferentially the head and neck of children ${ }^{4}$. Clinically, it presents as either solitary or multiple, well demarcated, and yellowish to tan nodules measuring several millimeters in diameter ${ }^{4}$. These two tumor types are compared in Table $1^{2,4,5}$.

Lipidized $\mathrm{FH}$ is a rare disease that is sometimes clinically misdiagnosed as juvenile XG. In this case, differential di-

Received February 26, 2018, Revised April 12, 2018, Accepted for publication April 19, 2018

Corresponding author: Min Kyung Shin, Department of Dermatology, School of Medicine, Kyung Hee University, 23 Kyungheedae-ro, Dongdaemun-gu, Seoul 02447, Korea. Tel: 82-2-958-8300, Fax: 82-2-969-6538, E-mail: haddal@hanmail.net ORCID: https://orcid.org/0000-0001-9834-7931

This is an Open Access article distributed under the terms of the Creative Commons Attribution Non-Commercial License (http://creativecommons.org/ licenses/by-nc/4.0) which permits unrestricted non-commercial use, distribution, and reproduction in any medium, provided the original work is properly cited.

Copyright (C) The Korean Dermatological Association and The Korean Society for Investigative Dermatology 

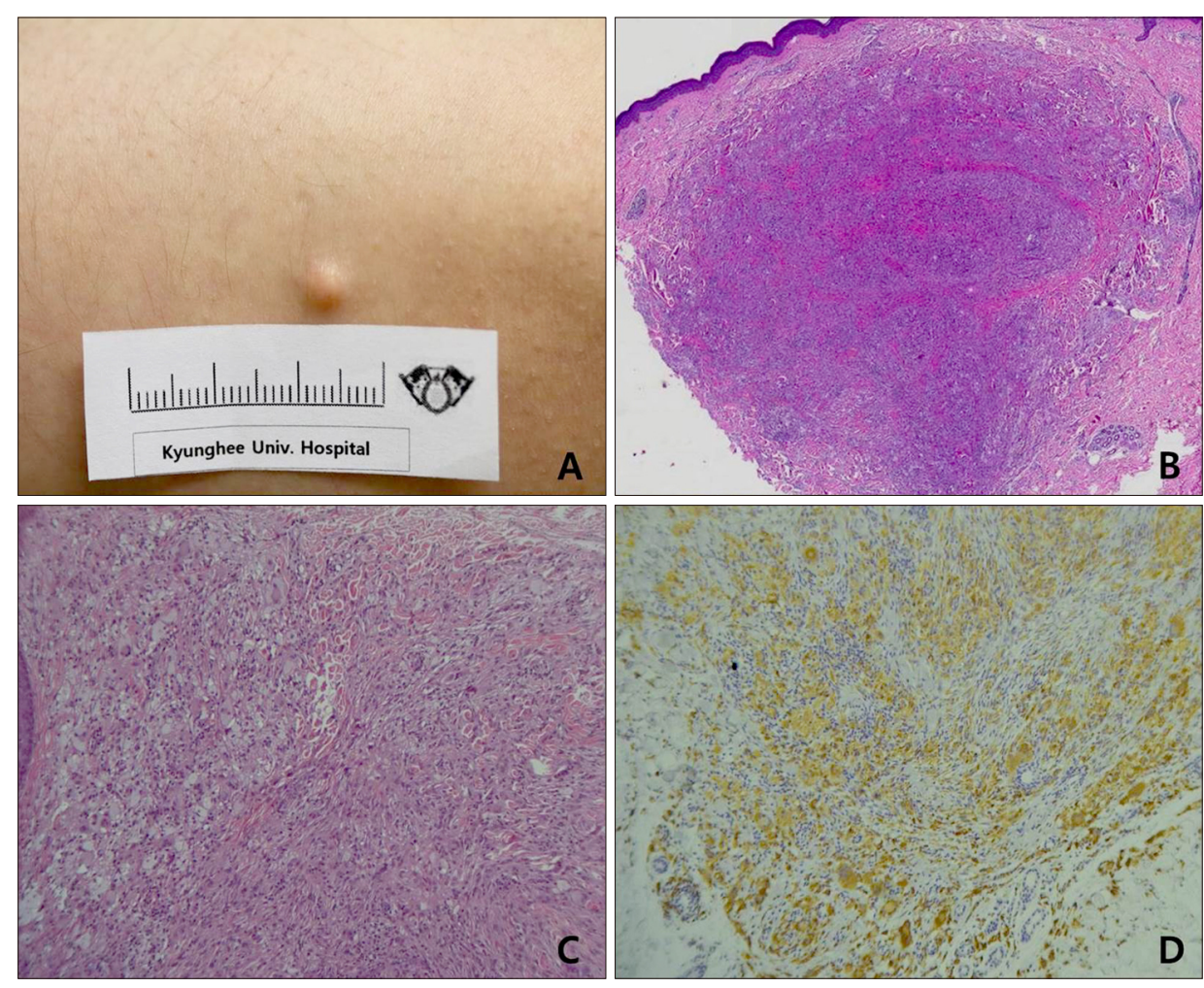

Fig. 1. (A) A solitary asymptomatic, 6-mm-sized, erythematous to yellowish-colored, dome-shaped nodule on the left forearm. (B) The dermal tumor abutted the epidermis and extended into the subcutis $(\mathrm{H} \& \mathrm{E}, \times 40)$. (C) A storiform pattern of arranged spindle cells and entrapped collagen bundles was noted $(\mathrm{H} \& \mathrm{E}, \times 100)$. (D) The foamy cells showed diffuse cytoplasmic staining with CD68.

Table 1. Comparison of lipidized fibrous histiocytoma $(\mathrm{FH})$ and juvenile xanthogranuloma $(\mathrm{XG})$

\begin{tabular}{|c|c|c|}
\hline Characteristic & Lipidized FH & Juvenile XG \\
\hline Tumor origin & Non-Langerhans histiocytes & Non-Langerhans histiocytes \\
\hline Clinical findings & $\begin{array}{l}\text { A solitary large (median } 2.5 \mathrm{~cm} \text { in diameter), } \\
\text { exophytic, yellowish to brownish nodule }\end{array}$ & $\begin{array}{l}\text { A yellowish to tan papulonodule measuring several } \\
\text { millimeters in diameter }\end{array}$ \\
\hline Histopathological findings & $\begin{array}{l}\text { Epidermal hyperplasia with foamy histiocytes, } \\
\text { peripheral entrapped dermal collagen fibers, and } \\
\text { fibroblast-like spindle cells in a storiform pattern } \\
\text { in the deep dermis }\end{array}$ & $\begin{array}{l}\text { A dense proliferation of foamy histiocytes, } \\
\text { cytologically bland mononuclear cells, } \\
\text { lymphocytes, and Touton giant cells }\end{array}$ \\
\hline Lipidized cytoplasm & Weekly lipidized cytoplasm & Heavily lipidized cytoplasm \\
\hline Immunochemistry & $\begin{array}{l}\mathrm{CD} 68(+), \mathrm{CD} 34( \pm), \mathrm{S}-100(-), \text { factor XIIIa }( \pm) \\
\operatorname{CD} 4(-), \operatorname{LCA}(-)\end{array}$ & $\begin{array}{l}\mathrm{CD} 68(+), \mathrm{CD} 34(-), \mathrm{S}-100( \pm), \text { factor XIIIa }(+) \\
\mathrm{CD} 4(+), \operatorname{LCA}(+)\end{array}$ \\
\hline Preferential site & Lower limbs, especially around the ankle & Head and neck \\
\hline
\end{tabular}

LCA: leukocyte common antigen.

agnosis was challenging, but the histopathology suggested that this lesion was lipidized FH. Therefore, when these two diseases cannot be clearly distinguished, histology and immunohistological techniques may be needed.

\section{ACKNOWLEDGMENT}

We thank the patient for granting permission to publish this information.

\section{CONFLICTS OF INTEREST}

The authors have nothing to disclose.

\section{ORCID}

Jong-Kil Seo, https://orcid.org/0000-0001-8822-6466

Eun-Jae Shin, https://orcid.org/0000-0002-4579-4911

Ki-Heon Jeong, https://orcid.org/0000-0001-6908-0932

Min Kyung Shin, https://orcid.org/0000-0001-9834-7931 


\section{REFERENCES}

1. Lin FL, Ho MC, Hu SL. Lipidized fibrous histiocytoma presenting as a keloid-like lesion. Dermatol Sinica 2008;26:252257.

2. Iwata J, Fletcher CD. Lipidized fibrous histiocytoma: clinicopathologic analysis of 22 cases. Am J Dermatopathol 2000; 22:126-134

3. Alves JV, Matos DM, Barreiros HF, Bártolo EA. Variants of dermatofibroma--a histopathological study. An Bras Dermatol 2014;89:472-477.

4. Kubota Y, Kiryu H, Nakayama J, Koga T. Histopathologic maturation of juvenile xanthogranuloma in a short period. Pediatr Dermatol 2001;18:127-130.

5. Kraus MD, Haley JC, Ruiz R, Essary L, Moran CA, Fletcher CD. "Juvenile" xanthogranuloma: an immunophenotypic study with a reappraisal of histogenesis. Am J Dermatopathol 2001;23:104-111.

\title{
MiR-92a-1-5p and miR-328-3p Are Up-Regulated in Skin of Female Pattern Hair Loss Patients
}

\author{
Mariya Aksenenko, Nadezhda Palkina, Anna Komina, Tatiana Ruksha \\ Department of Pathophysiology, Krasnoyarsk State Medical University, Krasnoyarsk, Russia
}

Dear Editor:

Female pattern hair loss (FPHL) is a disease with genetic predisposition that is characterized by miniaturization of hair follicles followed by hair volume reduction. Contrary to male androgenetic alopecia, FPHL is less obviously related to androgen metabolism, moreover, the increased number of FPHL cases in women above age 50 may imply estrogen's stimulatory role in hair growth ${ }^{1}$. Several intercellular cascades were observed as dysregulated in FPHL, including transforming growth factor- $\beta 1$ and stem cell factor/CKIT signalling ${ }^{2,3}$.

One of the most significant gene expression regulators at the posttranscriptional level are microRNAs which are capable of mRNA degradation and translation inhibition. Previous studies pointed out the role of microRNA in hair follicles normal functioning and pathological states' formation. Hence, miR-214 controls hair follicle morpho- genesis by $\beta$-catenin targeting ${ }^{4}$. As for miR-203, it regulates the transcription factor p63 expression which is essential for hair follicle development ${ }^{5}$. Epigenetic alterations in FPHL are not clear yet but supposed to play an evident role.

Following the above-mentioned reports, we carried out the microRNA profiling in normal female scalp, normal male interscapular skin, and FPHL skin in order to identify differences in microRNA expression pattern and better understand FPHL pathogenesis as well as to define novel FPHL therapeutic targets.

The affected scalp skin of women with FPHL $(n=3)$, at points $3 \sim 4$ on the Sinclair scale aged $43 \sim 55$ years, was obtained from equal frontal zone. Skin biopsies of control females $(n=5)$ were taken from the frontal region of the scalp of healthy donors. Normal male skin tissue $(n=5)$ was obtained from thoracic interscapular area of healthy

\footnotetext{
Received December 4, 2017, Revised April 19, 2018, Accepted for publication April 25, 2018
}

Corresponding author: Tatiana Ruksha, Department of Pathophysiology, Krasnoyarsk State Medical University, P. Zeleznyaka Str., 1, Krasnoyarsk 660022, Russia. Tel: 7-391-228-36-49, Fax: 7-391-228-08-60, E-mail: tatyana_ruksha@mail.ru ORCID: https://orcid.org/0000-0001-8142-4283

This is an Open Access article distributed under the terms of the Creative Commons Attribution Non-Commercial License (http://creativecommons.org/ licenses/by-nc/4.0) which permits unrestricted non-commercial use, distribution, and reproduction in any medium, provided the original work is properly cited.

Copyright (C) The Korean Dermatological Association and The Korean Society for Investigative Dermatology 